\title{
Soil Characteristics and Management Practices for Urban Residential Landscapes ${ }^{1}$
}

\author{
Brian J. Pearson ${ }^{2}$
}

\section{Introduction}

Construction of homes, roads, and other urban infrastructure modifies soil characteristics and usually results in high soil compaction, low rainfall infiltration, and restricted aeration (Craul 1985; Pouyat et al. 2007). Soil modification can be intentional to strengthen soil for engineered loads, such as house foundations and roadways, or unintentional as a result of heavy equipment usage and site traffic.

Soil compaction can occur quite readily. For instance, traveling over the same area in a landscape consistently with an SUV or noncommercial pickup truck only nine times can compact sandy soils to levels similar to those imparted by a dump truck or backhoe (Gregory et al. 2006).

High soil compaction negatively impacts plant establishment, growth, and quality in newly constructed communities. A thorough understanding of these urban soil characteristics is necessary to develop appropriate landscape management plans that maximize plant growth and establishment, while minimizing water use and nutrient runoff.

To better understand soil characteristics in recently built residential communities, 40 lots were sampled within nine newly established residential communities in Orange, Lake, and Seminole Counties in East Central Florida. These communities represented typical postconstruction landscape soil conditions in high-density metropolitan areas.
Soil samples were collected in the upper 3 inches of the soil surface from lots prepared for housing construction, but not yet built on. These samples were analyzed for texture, soil moisture retention, compaction, and infiltration.

\section{Soil Texture}

Soils are classified by their mineral particle size distribution. Soil particles are classified into three sizes: sand (0.05-2.0 mm diameter), silt $(0.002-0.05 \mathrm{~mm})$, and clay $(<0.002 \mathrm{~mm})$. All sampled soils were primarily sand. Sand-dominated soils are common throughout Florida, feel coarse and gritty to the touch, and are visually identified by the large proportion of large sand particles (Figure 1).

\section{Moisture Retention}

Sand-dominated soils possess low soil water retention because of the relatively large pore spaces between sand particles. Based on analysis of soil water retention from 40 newly constructed landscape soils, it was determined only 0.4 inches of moisture would be retained and available for plant use in the top foot of soil (Table 1).

To manage soils with low moisture retention, irrigation should be applied as needed determined visually by loss of plant turgor or when leaf wilt occurs. Turfgrass has shallow roots, so when $30 \%-50 \%$ of turfgrass displays visual signs of wilt during the day, irrigation should be applied, but not more than $0.5-0.75$ inches per event. If irrigation is applied

1. This document is ENH1218, one of a series of the Environmental Horticulture Department, UF/IFAS Extension. Original publication date September 2013. Visit the EDIS website at http://edis.ifas.ufl.edu.

2. Brian J. Pearson, assistant in-teaching, Environmental Horticulture Department, Mid-Florida Research and Education Center, UF/IFAS Extension, Apopka, FL 32703.

The Institute of Food and Agricultural Sciences (IFAS) is an Equal Opportunity Institution authorized to provide research, educational information and other services only to individuals and institutions that function with non-discrimination with respect to race, creed, color, religion, age, disability, sex, sexual orientation, marital status, national origin, political opinions or affiliations. U.S. Department of Agriculture, Cooperative Extension Service, University of Florida, IFAS, Florida A\&M University Cooperative Extension Program, and Boards of County Commissioners Cooperating. Nick T. Place, Dean 


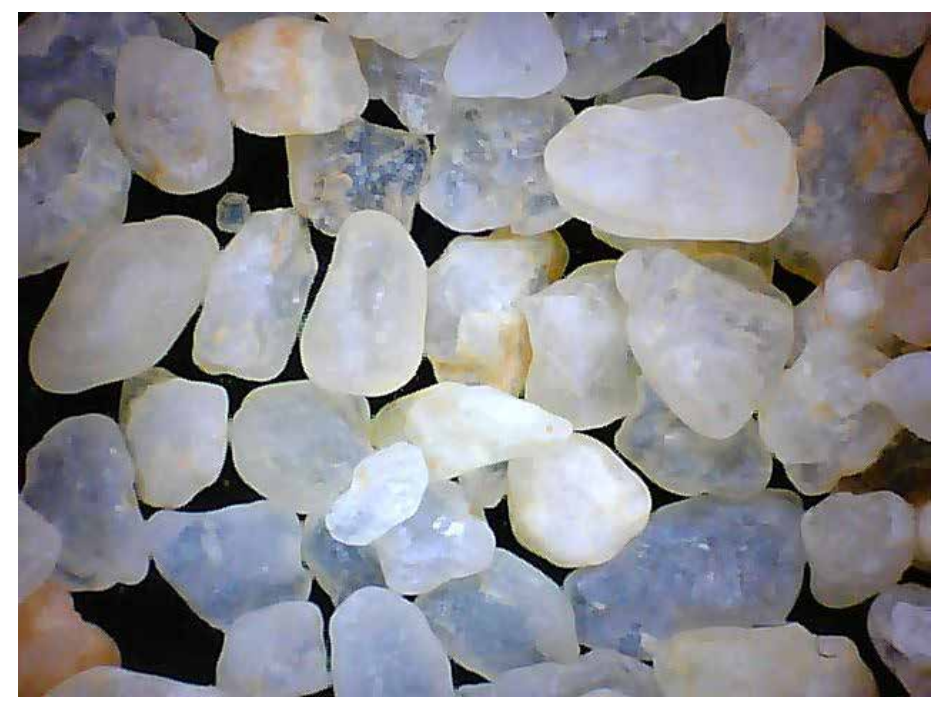

Figure 1. Coarse sand mineral particles at 40× magnification. Credits: Brian Pearson

in excess of this volume, water leaches below the top foot of soil and becomes unavailable to annual plants and turfgrass. Drip or microirrigation systems can be used to irrigate annuals, perennials, shrubs, and trees. These systems apply a slow, controlled application of water to the root zone of plant materials. This application method minimizes leaching of water below the root zone and provides high water use efficiency. Microirrigation systems are recommended for urban residential landscapes.

\section{Soil Compaction}

Site traffic and construction equipment almost always compact soils in newly constructed urban landscapes (Gregory et al. 2006; Randrup 1997). Visual indicators of compacted soil include excessive shallow and lateral root growth of plant materials, ponding of water, or excessive water runoff during rainfall or irrigation events. Soil compaction is quantified by calculating bulk density (mass of dry soil [g] per unit volume $\left[\mathrm{cm}^{3}\right]$ ). When bulk density exceeds $109 \mathrm{lb}$ $\mathrm{ft}^{-3}$ in sand-dominated soil, plant root growth beyond the planting hole is restricted or inhibited and results in poor plant establishment and growth (Daddow and Warrington 1983; Voorhees 1992).

Bulk density values recorded in newly constructed urban communities in Central Florida ranged from 103 to $111 \mathrm{lb}$ $\mathrm{ft}^{-3}$ (Table 1). A majority of sampled urban communities possessed bulk density values of approximately $109 \mathrm{lb}$ $\mathrm{ft}^{-3}$. Similar bulk density values have been observed in newly constructed communities in North Central Florida (Gregory et al. 2006).

Compacted soil conditions may be reduced by tillage. Tillage may be used to alleviate compacted conditions near the soil surface and should be done when preparing beds for shallow-rooted plant material, such as annuals, perennials, turfgrass, and shrubs. Organic matter should be amended into the top 4-8 inches of soil using a rototiller, shovel, or spading fork to increase the volume of soil pores, improve aeration, and increase nutrient-holding capacity. Sources of organic matter include composted manure, biosolids, and yard waste. These soil modifications help enhance plant establishment and promote proper plant growth and aesthetic quality.

\section{Soil Infiltration}

Soil infiltration is a measurement of how quickly water can pass through the soil surface. When soil infiltration rates are low, runoff or surface ponding of water may occur and be visible in the landscape. Soils can be tilled to increase soil water infiltration. Organic matter should be incorporated into the soil during tillage to improve soil particle aggregation and infiltration. When rainfall or irrigation volumes exceed infiltration, runoff may occur. Runoff is a concern in urban environments because it may lead to soil erosion and transportation of nutrients from targeted areas to surface water bodies (Figure 2).

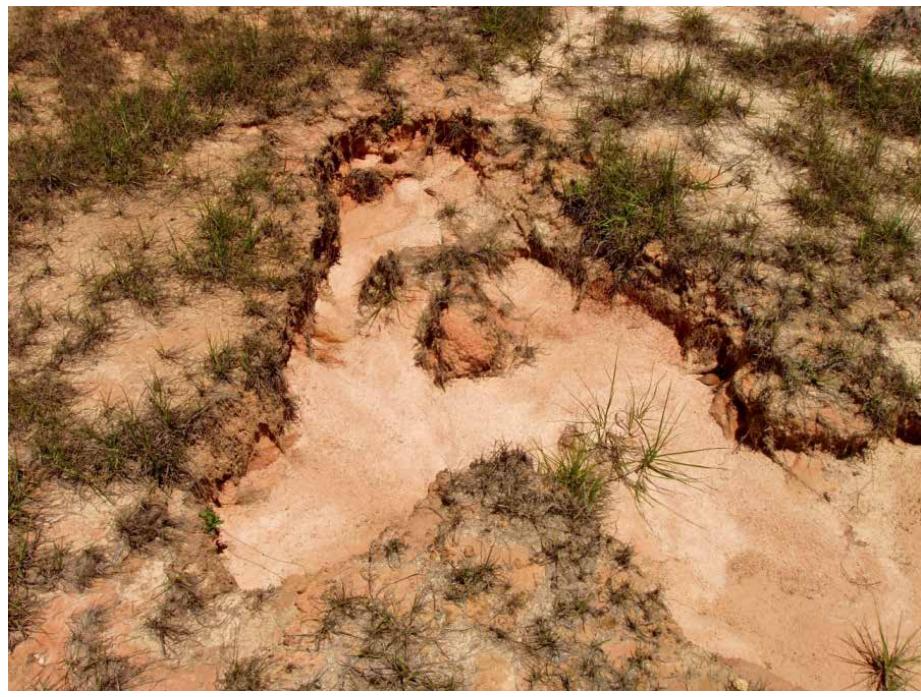

Figure 2. Soil erosion caused by stormwater runoff. Credits: Brian Pearson

Soil infiltration in newly constructed urban residential communities was highly variable and ranged from 0.8 to

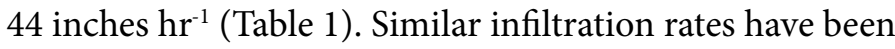
observed in North Central Florida communities (Gregory et al. 2006).

When runoff occurs, surface water quality can be degraded and lead to algal blooms in surface water bodies. Algal 
blooms may cause the water to appear blanketed by a thick green mass. Such blooms deplete oxygen concentrations in water and may result in fish kills.

Sand particles are silicon, glass-like crystals whose sharp edges have worn down. Sand-dominated soils exhibit poor nutrient-holding capacity; therefore, high fertilizer application rates should be avoided to prevent leaching of applied nutrients below roots. If nutrients leach below the plant root zone, they are unavailable and can enter groundwater supplies and degrade water quality. Slow-release fertilizer products reduce the risk of nutrient leaching and are recommended for sandy Florida soils.

Rain gardens can be constructed as a management tool in areas where runoff or ponding occur to retain stormwater and allow infiltration on-site, thus reducing soil erosion and nutrient transport. Low-growing plants or ornamental grasses are ideal for rain gardens because their physical structure helps reduce runoff and encourages infiltration (Figure 3).

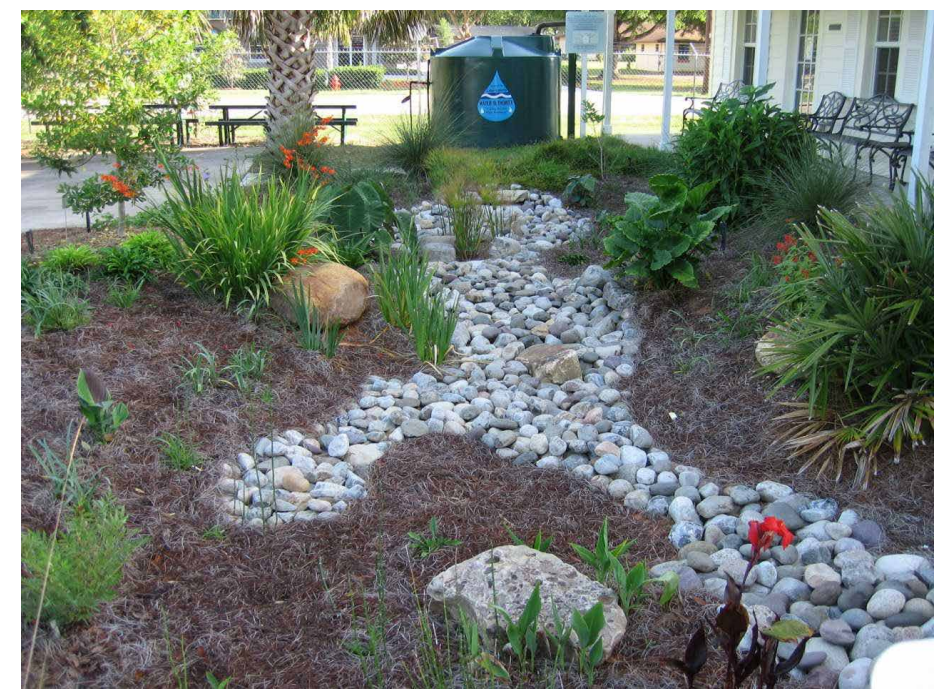

Figure 3. Rain garden created to retain stormwater and enhance onsite infiltration. Credits: Juanita Popenoe

\section{Summary}

Newly constructed urban residential landscape soils sampled within Central Florida are dominated by large sand particles and possess low soil moisture retention. Therefore, irrigation and fertilizer applications should be managed to match site conditions and prevent overapplication of water and nutrient leaching. Sampled soils in newly developed urban residential communities were found to be highly compacted and likely to inhibit plant establishment and growth. Compacted soil conditions should be repaired through tillage to maximize plant establishment success.
Soil infiltration rates in sampled landscapes were highly variable. Where soil infiltration is low or runoff is observed, rain gardens may be constructed to enhance infiltration and reduce the risk of nutrient transport.

\section{References}

Craul, P. J. 1985. "A Description of Urban Soils and Their Desired Characteristics." Journal of Arboriculture 11: 330-339.

Daddow, R. L., and G. Warrington. 1983. Growth-Limiting Soil Bulk Densities as Influenced by Soil Texture. Fort Collins, CO: USDA Forest Service.

Gregory, J. H., M. D. Dukes, P. H. Jones, and G. L. Miller. 2006. "Effect of Urban Soil Compaction on Infiltration Rate." Journal of Soil and Water Conservation 61 (3): 117-128.

Pouyat, R. V., I. D. Yesilonis, J. Russell-Anelli, and N. K. Neerchal. 2007. "Soil Chemical and Physical Properties That Differentiate Urban Land-Use and Cover Types." Soil Sci. Soc. Am. J. 71 (3): 1010-1019.

Randrup, T. B. 1997. "Soil Compaction on Construction Sites." Journal of Arboriculture 23 (5): 207-210.

Voorhees, W. B. 1992. "Wheel-Induced Soil Physical Limitations to Root Growth." Advances in Soil Science 19: 73-95. 
Table 1. Summary of soil characteristics from 40 sites in Central Florida

\begin{tabular}{|c|c|c|c|}
\hline Soil sample location & $\begin{array}{l}\text { Mean plant available water } \\
\left.\text { (in. } \mathrm{ft}^{-1}\right)\end{array}$ & $\begin{array}{l}\text { Mean bulk density } \\
\qquad\left(\mathrm{lb} \mathrm{ft}^{-3}\right)\end{array}$ & $\begin{array}{l}\text { Mean infiltration rate } \\
\left.\text { (in. } \mathrm{hr}^{-1}\right)\end{array}$ \\
\hline Orange County & 0.4 & 104.8 & 13.9 \\
\hline Lake County & 0.4 & 107.9 & 18.7 \\
\hline Seminole County & 0.3 & 107.2 & 10.8 \\
\hline
\end{tabular}

